\title{
The Role of the Concept Maps in the Development of a Pedagogical Project of a Business Course
}

\author{
Paulo H. Trentin ${ }^{1, *}$, Fábio Gerab ${ }^{1}$, Hong Y. Ching ${ }^{2}$ \\ ${ }^{1}$ Mathematics Department, Centro Universitário da FEI, São Bernardo do Campo, Brazil \\ ${ }^{2}$ Business Department, Centro Universitário da FEI, São Bernardo do Campo, Brazil \\ *Corresponding author: trentin@fei.edu.br
}

Received September 17, 2014; Revised November 20, 2014; Accepted December 04, 2014

\begin{abstract}
This article aims at describing an experience in the use of Concept Maps in a competency - based pedagogical project in a Business course of a Brazilian higher education institution. The basis for our considerations is the Course Pedagogical Project (CPP), Parecer (Official Review) 776/97 of the National Education Council (CNE) and Resolution 04/2005 of the CNE. As theoretical basis, meaningful learning was utilized in which construction of concept maps represents a methodological possibility for the student to achieve understanding about the integration and connections among distinct course subjects scheduled for each semester in a four years course. The course for construction of Concept Maps should also encourage the student to address meaning for the specific constructs of each of the curriculum components. Any implementation of a new pedagogical approach, such as the competencies pedagogy, requires a change of mindset and of paradigms of different players: the course coordinator, the professor and the students. It also requires a reorganization of educational institutions that should be committed to the student's qualification.
\end{abstract}

Keywords: Concept Map, Business Course, curriculum, Pedagogical Project

Cite This Article: Paulo H. Trentin, Fábio Gerab, and Hong Y. Ching, "The Role of the Concept Maps in the Development of a Pedagogical Project of a Business Course.” Journal of Business and Management Sciences, vol. 2, no. 5 (2014): 105-110. doi: 10.12691/jbms-2-5-3.

\section{Introduction}

The Parecer 776/97 of the Brazilian National Education Council (CNE), which presents the curriculum guidelines for undergraduate courses, states that undergraduate courses must be conducted through Curriculum Guidelines and abandon the traditional perspective of knowledge and information transmission. Such courses should provide basic and solid education, preparing the students to meet the challenges of social transformation, labor market and conditions of professional practice.

Based on this Parecer, the Director of the Chamber of Professional Qualification of CFA-Conselho Federal de Administração (Federal Business Council), in Nov/Dec 2013 issue of RBA-Revista Brasileira de Administração (Brazilian Business Magazine), maintains that a professor should become a mentor or mastermind and not a mere knowledge transmitter, helping to change the role of the student from supporting to becoming the "protagonist" of the learning process.

In other words, he suggests that the model of higher education should make a transposition: from teaching to learning. Therefore, the teacher should use active learning methodologies that seek to develop the skills required by the labor market. This is in line with [2] Antunes's position that, in the classroom, the difference in educating for competences is materialized in how information is presented, giving it a context and linking it to the student's professional life while, seeking to build knowledge with the learn.

The flexible curriculum is discussed and defended in the work of Pereira, Mozer and Brito [26]. They studied the flexibility of the curriculum of the Business course through the professor's beliefs. Their proposal was based on the need to pervade teaching and learning that valued competence and developed skills for professional practice, enhancing the capacity for abstract reasoning and valuing ethical behavior and civic principles. In this study the curricular flexibility is understood and viewed, as a proposal to build curriculm that does not follow the sequential and hierarchical organization of disciplines, while focusing, according to Freitas and Amorim [13], on the interdisciplinarity and the interface between theory and practice.

In a changing perspective, a new course pedagogical Project (CPP) was introduced in the Business course of a higher education Institution (HEI), located in the Metropolitan Region of São Paulo (MRSP). It incorporates in its body some didactic and pedagogical developments necessary to build competences and skills throughout the course. Concept Mapping was chosen as a learning methodology to be used in all curriculum components of the course.

\section{Literature Review}


Until present moment the undergraduate course has historically been based on a curriculum traditionally teacher-centered.The teacher would present knowledge while the student would passively receive the load of information and reproduces it during the exams. Evaluation consisted of written papers in mid-term and at the end of each term.

In the remodeling of the pedagogical Project in this course the teacher is viewed as mediator while the student is seen as a co-participant. in constructing and negotiating knowledge. For the student, he should actively participate in the negotiation process with scientific knowledge. For the development of competences, two sets of documents were researched: National Curricular Guidelines from the National Education Council (Brasil, Resolução 04/2005) [5] and 2011 National Research from CFA [6] Federal Business Council.

It is important to stress that the need for redesigning the course arose from a social demand. Understanding that the student brings with him prospects, ambitions and different ways of conceiving his environment, which sometimes diverge from the scientific knowledge that is the subject of discussions at university. The university, as a human creation, is the official site for dissemination of scientific knowledge. In that sense scientific production appears as the suitable methodology for its presentation to the community. According to Monteiro and Pompey Junior [19], they see a concern for adapting scientific knowledge to the school context, searching for examples, languages and appropriate ways so that this knowledge acquires significance for apprentices, which indicates a tendency to didactic transposition ideas.

Over time, the social demands have imposed on to the university an opening for the recognition of other possible referrals to discussion about the established scientific knowledge. Recognizing, for example, the existence of educational, scientific and day to day work, is almost as necessary as understanding that there is not a hierarchy among these types of work. This position is supported by authors like D'Ambrosio [7, 10], Knijinik [17] and Monteiro and Pompey Junior [19], among others. In this sense, the university is understood as a place in which educational, scientific and day to day work meet and interact synergistically.

In the context we are discussing, in which there is an opening for other forms of work besides the scientific and the educational, the purposes of Liberating Education (Freire [12]) finds its niche. In the Freirean perspective, student is understood as someone that participates in the process of negotiation, which takes place in the school environment, between the school and non-school knowledge (everyday).

Given that student motivation is an important factor in academic performance, and that such motivation can be influenced by teaching methods, Muritiba et al [22], in their study with Bussines undergrad students, correlated the preference of these students by several teaching methods with their psychological profile. In that sense, it is necessary to understand what learners bring with them. Their study found that, regardless of the psychological profile, students prefer, in general, active teaching methods. The authors also found that the more extroverted the student is, greater is his preference for active methodologies. On the other hand, introverted individuals tend to not accept more passive teaching methods. It is advisable to not consider students as a uniform group, with similar characteristics, assuming that everyone receives the same content, transmitted at the same rate, regardless of the learning style in which the student is most responsive. The authors suggest diversifying teaching methods used in the classroom as an effective practice to improve teaching and learning. Thus, it is interesting the understanding of the Guiney [14] considering that many teachers are adopting new strategies to contribute with learning of the students.

In that sense, teaching practice is seen as a mediator between formal and informal knowledge. To support this statement, we have Ausubel's considerations [1] about meaningful learning as the scenario for proposing active methodologies for teaching and learning in the pedagogical practice. In addition, it is possible to note that Ausubel's ideas resonate with those of Novak and Canas [23] in their studies on concept maps. Hazoff Junior and Sauaia [15] conducted a comparative study with undergrads of two institutions. Participants were divided into two groups within the same institution and subjected to the same content and assessment. Each group experienced a distinct pedagogical approach: one highly teacher-centered (passive) and another highly studentcentered (active). It was found that there was a statistically higher academic performance associated to the group subjected to student-centered approach, for both institutions evaluated. This result corroborates those obtained by Muritiba et al [22], in which the preference for active teaching methods can influence motivation (attitude) and performance of a significant number of students.

Our understanding of meaningful learning is related to the allocation of idiosyncratic meanings. The Concept Mapping developed by educators and students tends to reflect the meanings attached to a particular construct in question. Thus, the maps referenced by educators as a teaching resource, as well as the maps produced by students will have unique and personal components. Dolci, Bergamaschi and Vargas [11] used concept maps to show the main theories and methodologies related to the development and structuring of Systemic Thinking and their relationships from a retrospective survey from 1960 to 2010. The choice for conceptual maps was justified by their usefulness in locating and identifying relationships between theories and concepts through graphical representation, which can lead to formation of new knowledge.

We understand there are various possibilities to work with construction of concept maps. The first relates to support of education, where maps can be used to give an instruction on an activity to be performed. The second is to use concept maps to establish a connection between the knowledge of the student and the alternative resource for learning. Another possibility is to use them for development of content, ie, map is built when a particular theme or content is presented and later is revised, revisited and reworked during the lessons. A fourth possibility would be the synthesis of contents worked on that, at the end of a lesson or a course. Concept Maps can represent a schematic summary of what was discussed, on the set of important concepts of an area of knowledge. The fifth possibility is the use of Concept Maps as an sharer of 
information showing the knowledge built. We understand as Tergan [27] that concept mapping is designed to be for a constructivist approach to learning. In this sense, the concept map can express an external representation of the ideas and concepts during the process of learning.

Moreover, there is also another possibility that would be the use of Concept Maps as a method of assessment and portfolio. The use of maps avoids the traditional diagnosis and retrieval of knowledge stored in memory. It represents an alternative consistent with the theory of meaningful learning assessment because it focuses on the exposure that the student does about the relationships between previous and new knowledge. Together, portfolio and maps can show development of content highlighting the possibilities of storage maps of some conceptual tools. It should express critical thinking of students who actually got knowledge on certain construct.

Students should be encouraged to reflect on their thinking process, making permanent records from the interactions among the others constructs that are presented in the educational environment. For Novak and Gowin [25] this involves negotiating with concepts, joining them and separating them permanently. The act of making and remaking the concept maps can assist this process, in a relevant way, when shared with others. Novak and Cañas [24] emphasize that a concept map is never finished. The construction of maps is not just a tool to capture, represent and store knowledge, it is an alternative to knowledge enrichment.

According Dolci et al [11] the structure of concept maps depends on the context where they are being drafted. In our view, there is no conceptual map "suitable". The educator or mediator should not, at least initially, introduce students to the conceptual map of a given construct. The ideal is propose for the student to develop a concept map for the content according to the meanings that he, educator (mediator) attributes to concepts in order to exploring the significant relationships. Similarly, he should never expect from the student the conceptual map "correct" or according with a model map. The educator should expect a conceptual map that adequately established relations between concepts, according to the particular construct and the respective particular area of knowledge.

In the process of concept mapping, the most important is to assess whether it gives evidence that student is learning the content and can express it. It is with this purpose that construction of maps must be understood. The concept maps provide information about how someone was "touched" by certain knowledge. Thus, such constructions reveal a personal way to see, feel, and react. Maps are representations of alternative perspectives among students and teachers, or between peers. If two teachers, with equal knowledge, develop a concept map for certain content, their maps will have similarities and differences. The two maps can show good understanding of content without being able to say that one is better than another, much less that one is right and another wrong. This serves as an indication as to the conceptual maps developed by the students. However, care is needed to not accept any proposition, because some constructions can suggest misunderstandings.

As argued by Moreira [20,21], in the moment the teacher presents to the student a conceptual map as being the correct map, about certain content, or when he requires from the student a correct map, he will be promoting (like many other teaching resources) a mechanical learning, not meaningful learning. Concept mapping is dynamic and is constantly changing. If the learning is significative, cognitive structure is constantly being reorganized by progressive differentiation and integrative reconciliation and, consequently, maps designed today will be different tomorrow. From this analysis, concept mapping is essentially qualitative. The teacher-mediator, instead of bothering to assign a score to the map elaborated by the student, should seek to interpret the information given by the student on the map in order to obtain evidence of meaningful learning. Oral or written explanations from the student, with respect to his map, should facilitate task of the teacher.

In the other hand, the work with Concept Maps should not allow understanding that this educational resource is little applicable, even though the idiosyncrasy that pervades its elaboration can be a important factor. By a conventional point of view, Concept Maps might not be attractive neither for educators, who prefer to stay in the comfort zone, nor for students accustomed to memorizing content to reproduce them in evaluations and exams. According to Correia, Junior Silva and Romano [5], the incorporation of Concept Maps in the routine of the classroom requires openness to uncertainty, since they allow expressing the idiosyncrasies present in the cognitive structure of the students. This feature is opposed to determinism present in multiple-choice tests, or the essay questions that have only one "right" answer. The use of MCs as an evaluation strategy imposes a revision in the relationships that the teacher and students establish in the classroom. According to Koc [18], concept maps have been used in various ways including to evaluate learners performance.

Working with concept mapping for dealing with uncertainty and subjectivity, there are some opportunities so that the dialogue and interactions among peers, such as student and student or student and teacher, can be established in the educational environment.

\section{Research Methodology}

As regards the definition of the type of research it is possible to say that is the descriptive method, because it seeks to describe and report one experience in the use of Concept Maps in the pedagogical project of a Business Course, driven to develop student's competences and skills. To complement the study internal and external documents such as: the CPP of the course, the Parecer 776/97 of the National Education Council (CNE) [4], the CNE 04/2005 [3] Resolution and the National Research CFA / CRA [6] were analyzed.

If the guidelines defined in the CPP have as challenge to break the paradigm of the teacher as a transmitter and / or reproducer of knowledge, and also if the model proposes the transition from a model based on teaching for another based on learning, it is possible to realize that "new" methodologies are necessary for learning. Therefore, the following methods may be adopted by teachers in their classes, including: bringing together theory and practice, resolving actions, conceptual maps, 
interdisciplinary and integrative work. Jennings [16] also proposes various learning methods, as case study, problem-based work, role play, group project, oral and written presentation, activity in the laboratory and conceptual map among others.

The Concept Map was chosen as one learning methodology to be used in all curriculum components of the course. The construction of concept maps as an strategic component of the new course project acts as a catalyst of the interactions among all the curricular components scheduled for each cycle. Hopefully, it is expected from the student that he, while making the construction of maps, can understand the intrinsic and extrinsic relations established between each of the curriculum components. It is worth remembering that the curriculum components naturally emerged from the analysis and definition about what skills and competencies are intended to be developed in the student. Moreover, as highlighted previously, the construction of concept maps should work with a portfolio that adds to each class, in each curricular component specifically, the knowledge that comprises its corpus. Adjustments and (re)designs that are needed will be readily incorporated by the faculty of this course.

\section{Analysis and Discussion: Some Possibilities}

Novak and Cañas [24] noticed the inclusion of concept maps in several Science textbooks as a way to summarize the knowledge acquired by students after studying a unit or chapter. This inclusion favors the perception of the relationship between each part and the whole of the content discussed.

In the new PPC, teachers encouraged the students to make use of the conceptual mapping in class. Figure 1 displays the application example of the conceptual map of the curricular component called Foundations of Macroeconomics.

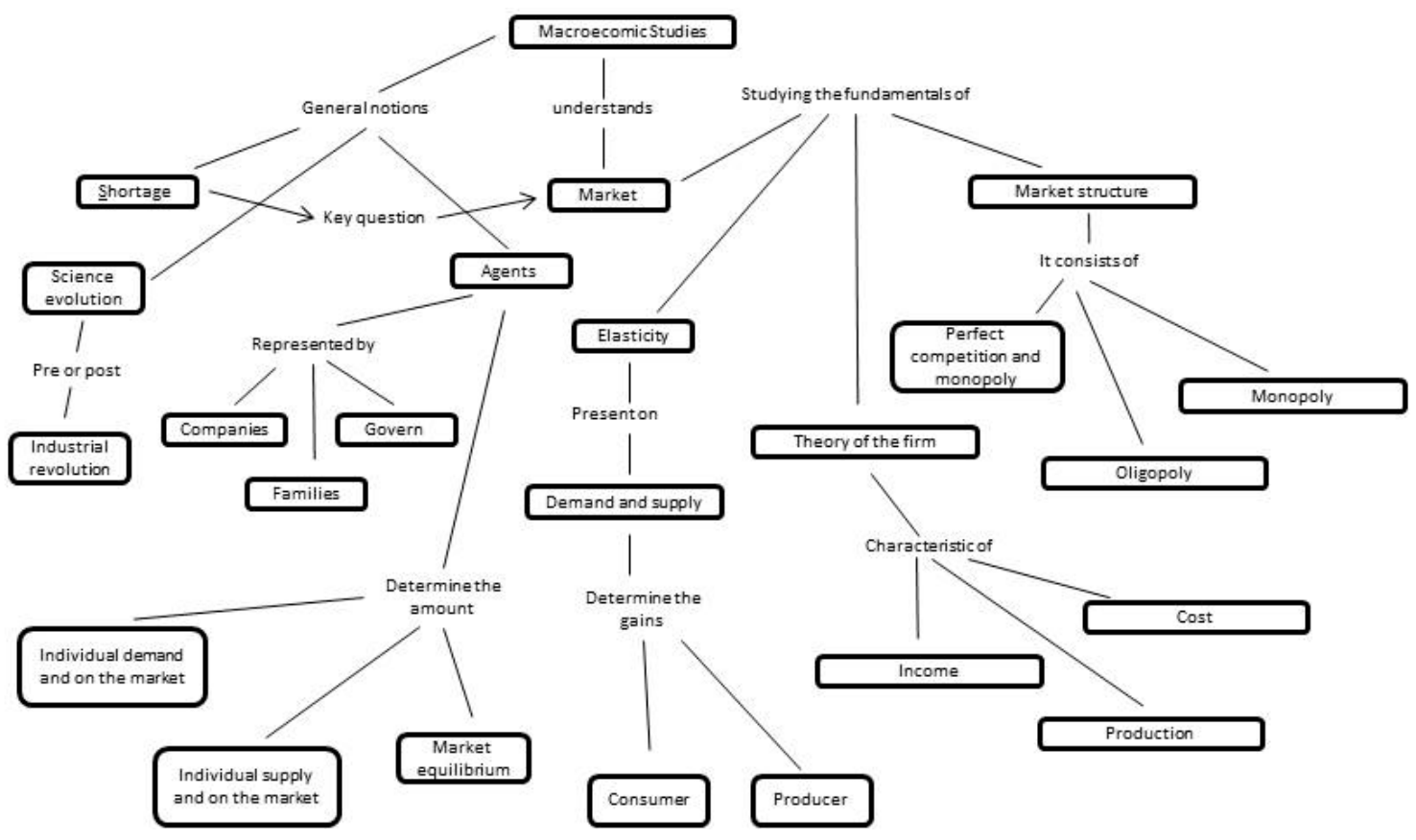

Figure 1. Conceptual Map of the curricular component Fundamentals of Macroeconomics

From these maps, students should still relate the crucial elements of each curricular component and agglutinate them in the map of the Integrative Curricular Component (there is one Integrative Curricular Component for each course cycle). This procedure aims to create links between the contents of the Integrative Curricular Component in an interdisciplinary way simulating an organizational setting. The goal is to express to the students the idea of a significant interconnection between different curriculum components. Thus, they can perform a consistent relationship between reflection and content. Furthermore, it is expected that they understand the interrelationship between the main basics of management science. About the Integrative Component, it is necessary to mention that it fulfills the role of agglutinating knowledge presented and discussed in the other components of its cycle, so that all the knowledge makes sense to the student. This desmifies the common understanding that the components are disciplines in the format of isolated "knowledges". To ensure this happens effectively, the use of concept maps was introduced as a learning tool.

Figure 2 displays an example of integration of the curricular component Foundations of Macroeconomics with the integrative component of the corresponding cycle, called Fundamentals of Management. The next challenge is related to assess the conceptual map. To do so, we understand that in the evaluation, the idea should be to get the information about how the student structures, ranks, differentiates and integrates the most important concepts of a particular curricular component [18]. The teacher will evaluate the development of the conceptual map in his component through a graduation note for each proposed indicator or criteria (see Table 1 below). Five assessment indicators and four forms of graduation were chosen.

This evaluation method is similar to that one proposed by Jennings [16] in which he used six criteria - length, interconnectivity, connecting elements (links), efficiency of links, layout and development over time - and, four scoring - unacceptable, acceptable, good and exemplary. 


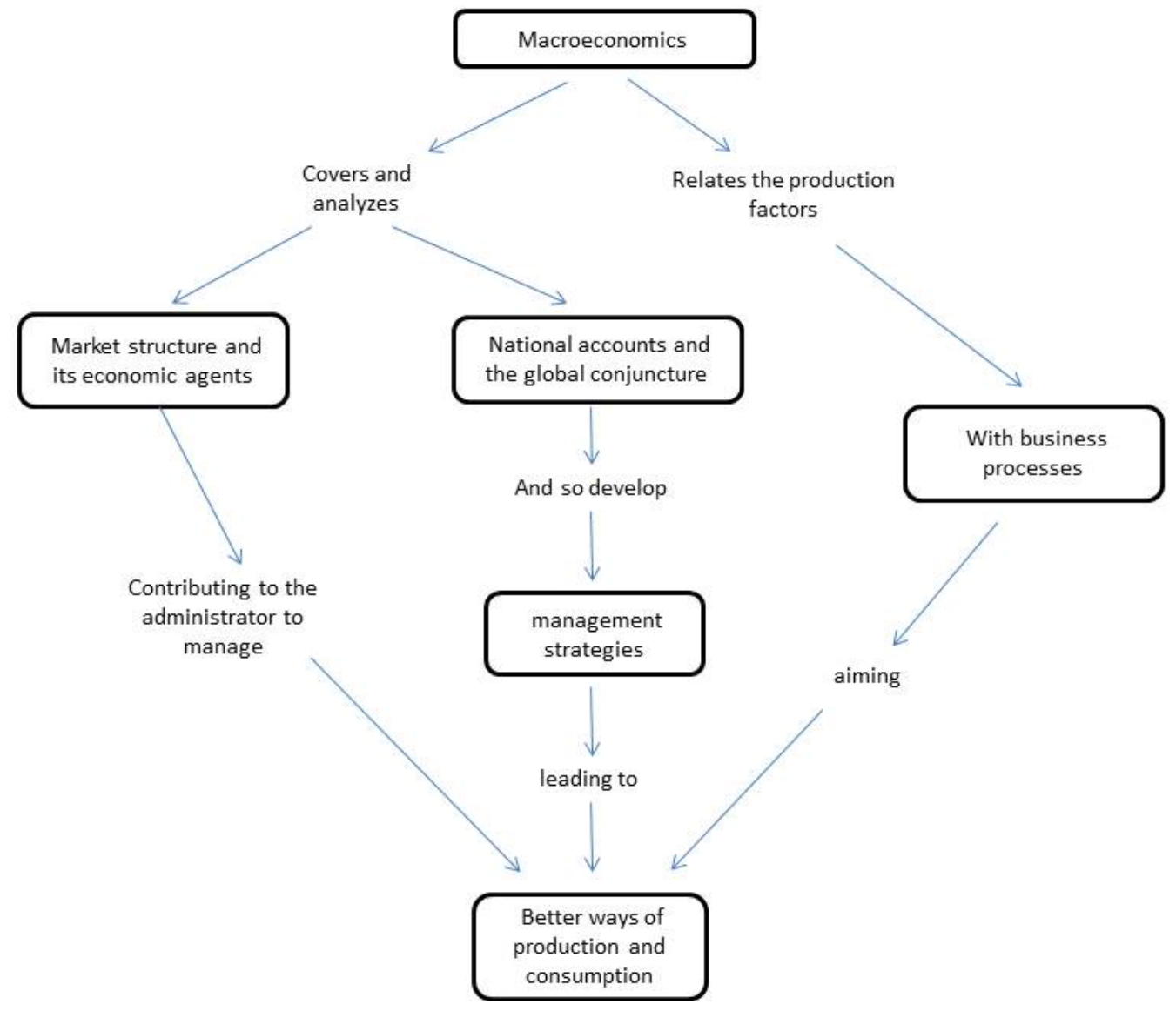

Figure 2. Fundamentals of Macroeconomics integrative curricular component

Table 1. Ranking of the score in each indicator

\begin{tabular}{|l|l|l|l|l|}
\hline Indicator degree & 1 & 2 & 3 & 4 \\
\hline Indicator / Criteria & $\begin{array}{l}\text { Does not meet the } \\
\text { indicator }\end{array}$ & Meets the basic & Proficient & Striking \\
\hline $\begin{array}{l}\text { Expresses the } \\
\text { appropriate connections }\end{array}$ & $\begin{array}{l}\text { Expressed no } \\
\text { connections or it is } \\
\text { not clear }\end{array}$ & $\begin{array}{l}\text { There is some evidence of } \\
\text { logic and analytical ability }\end{array}$ & $\begin{array}{l}\text { Expressed the connection in a } \\
\text { clear form }\end{array}$ & $\begin{array}{l}\text { Added the connections by a } \\
\text { creatively way }\end{array}$ \\
\hline $\begin{array}{l}\text { Analyzes all } \\
\text { information available }\end{array}$ & $\begin{array}{l}\text { Not considered the basic } \\
\text { information }\end{array}$ & $\begin{array}{l}\text { Considered the basic } \\
\text { information to do the } \\
\text { connections }\end{array}$ & $\begin{array}{l}\text { Considered all available } \\
\text { information }\end{array}$ & $\begin{array}{l}\text { Used the information to do } \\
\text { the best connections }\end{array}$ \\
\hline $\begin{array}{l}\text { Understands the subject } \\
\text { in which he is involved }\end{array}$ & $\begin{array}{l}\text { Does not demonstrate } \\
\text { knowledge about the } \\
\text { subject }\end{array}$ & $\begin{array}{l}\text { Understands it but does not } \\
\text { see the interdependencies }\end{array}$ & $\begin{array}{l}\text { Demonstrates clear } \\
\text { understanding of the } \\
\text { connections between subjects }\end{array}$ & $\begin{array}{l}\text { Shows the } \\
\text { interdependencies } \\
\text { creatively }\end{array}$ \\
\hline $\begin{array}{l}\text { Emphasizes standards } \\
\text { for the results }\end{array}$ & Low quality standard & $\begin{array}{l}\text { Results within the regular } \\
\text { expected standard }\end{array}$ & $\begin{array}{l}\text { Good standard for the present } \\
\text { results }\end{array}$ & Standard of excellence \\
\hline $\begin{array}{l}\text { Discussion of different } \\
\text { points of view }\end{array}$ & $\begin{array}{l}\text { Not open to other } \\
\text { opinions }\end{array}$ & $\begin{array}{l}\text { Accepts different opinions } \\
\text { but with resistance }\end{array}$ & Open to different opinions & $\begin{array}{l}\text { Builds upon others and } \\
\text { several distinct opinions }\end{array}$ \\
\hline
\end{tabular}

\section{Conclusion}

This article does not intend to offer a comprehensive analysis on the use of concept maps in a Business course. Nor it intendes to define a model to be followed or adopted by other Higher Education Institutions. This article aims to describe the experience in the use of Concept Maps in a Business Course. Efforts to innovate teaching practices in such course has propelled this HEI and its faculty to seek for alternatives that include the elaboration of this entire new curriculum and its CPP. We understand that it is a continuous process that is built as challenges present themselves. This project is bold for demanding change in the paradigm as well as because there are very few similar experiences in Brazil, notably concerning the Business course.
Finally, the construction of concept maps should also encourage the student to learn in a significative way the specific constructs of each curriculum component. Any implementation of a new pedagogical approach such as the competencies pedagogy requires from all actors involved a change in the way of thinking and a break with paradigms.

\section{References}

[1] Ausubel, D. P. (1976). Psicología educativa: um punto de vista cognoscitivo. México, Editorial Trillas. Traducción al español de Roberto Helier D., de la primera edición de Educational psychology: a cognitive view.

[2] Antunes, C.(2002). Como desenvolver as competências em sala de aula. 4a ed. Rio de Janeiro: Vozes.

[3] Brasil.(2005). Conselho Nacional de Educação. Resolução n 4 de 13/07/2005. Brasília. 
[4] Brasil.(1999). Conselho Nacional de Educação. Portaria 776/77 de 03/12/1997. Disponível no http://portal.mec.gov.br/setec/arquivos/pdf_legislacao/superior/leg isla_superior_parecer77697.pdf. Brasília.

[5] Correia, P.R.M.; Silva, A.C.; Romano Junior, J.G. (2010). Mapas Conceituais como ferramenta de avaliação na sala de aula. Revista Brasileira de Ensino de Física, São Paulo, v.32, n.4, p.4402144028.

[6] CFA/CRA Conselho Federal de Administração. (2011). Pesquisa Nacional. Brasília, $5^{a}$ edição.

[7] D'Ambrósio, U. (1985). Socio-cultural bases for Mathematics Education. Campinas, Editora: UNICAMP/Autênctica.

[8] D'Ambrósio, U. (1986). Da realidade à ação. Reflexões sobre Educação Matemática. Campinas: Editora: UNICAMP/Autêntica.

[9] D'Ambrósio, U. (1992). Reflexões sobre História, Filosofia e Matemática, in BOLEMA - Boletim de Educação Matemática, especial n-2, pp. 46-60, Rio Claro: UNESP, 1992.

[10] D'Ambrósio, U. (2001). Etnomatemática, um elo entre as tradições. Belo Horizonte: Editora Autêntica.

[11] Dolci, P. C.; Bergamaschi, E.; Vargas, L. (2013).Visão Sistemica do Pensamento Sistêmico: Uso de Mapas Conceituais. R.Adm. Faces Journal v.12, n.1, p. 33-50.

[12] Freire, P. (2013). Pedagogia do Oprimido [Recurso Eletrônico], Editora: Paz e Terra.

[13] Freitas, T.S.; Amorin, T.N.G.F.(2000). Diretrizes Curriculares x Flexibilização...Aonde vamos? Realmente queremos ir? Pág. 5-18. In: Anais do XI Enangrad: Encontro Nacional dos Cursos de Graduação em Administração. Salvador, BA, 23-27.

[14] Guiney, E. (2001). Coaching Isn’t Just For Athletes: The Role of Teacher Leaders. PHI Delta Kappan, the online version: http://pdk.sagepub.com.

[15] Hazoff Junior, W.; Sauaia, A.C.A. (2008). Aprendizagem Centrada no Participante ou no Professor? Um Estudo Comparativo em Administração de Materiais. RAC, V.12, n.3, p. 631-658.
[16] Jennings, D. (2012). Concept maps for assessment. UCD Teaching and Learning, UCD, Ireland.

[17] Knijinik, G. (1996). Educação e Resistência - Educação Matemática e Legitimidade Cultural. Porto Alegre: Artes Médicas.

[18] Koc, M. (2012). Pedagogical Knowledge Representation through concept mapping as a study collaboration tool in teacher education. Australasian Journal of Educational Technology, p. 28-32.

[19] Monteiro, A. e Pompey Jr., G. (2001). A matemática e os temas transversais. São Paulo: Moderna.

[20] Moreira, M.A. (2006). A teoria da aprendizagem significativa e sua implementação em sala de aula. Brasília: Ed. Universidade de Brasília.

[21] Moreira, M.A. e Masini, E.F.S. (2006) Aprendizagem significativa: a teoria de aprendizagem de David Ausubel.São Paulo: Centauro Editora. $2^{a}$ edição.

[22] Muritiba, P.M.; Muritiba, S.N,; Casado, T. (2010). Personalidade e Preferência por Métodos de Ensino: Um Estudo com Graduandos em Administração. R. Adm. Faces Journal, V.9 n.2, p. 65-85.

[23] Novak, J., Canãs, A. (1998). Conocimiento y aprendizage: los mapas conceptuales como herramientas facilitadoras para escuelas y empresas. Madrid: Alianza Editorial. Revisado e publicado em espanhol, em 2005, na Revista Chilena de Educação Científica, $4(2): 38-44$.

[24] Novak, J.D.; Cañas, A.J. (2010). A teoria subjacente aos mapas conceituais e como elaborá-los e usá-los. Práxis Educativa, Ponta Grossa, v.5, n.1, p.9-29.

[25] Novak, J.D. e Gowin, D.B. (1996). Aprender a aprender. Lisboa: Plátano Edições Técnicas.

[26] Pereira, M. C., Mozar J. B., Brito, V.G.P. (2013). "Movimento de Re-Construção Do Currículo No Ensino Em Administração: Um Estudo Sobre O Imaginário Dos Docentes Em Uma IES. Revista Eletrônica de Administração 12.2

[27] Tergan, S-O. (2005). Concept Maps for Managing Individual Knowledge. Lecture Notes in Computer Science Volume 3426, pp 185-204. Institut Für Wissensmedien (IWM). 